\title{
Umbilical Cord Unmeasured Anions and Tissue Acid Levels According to Stewart's Method in Term Newborn Infants and The Impact of Delivery Mode on These Parameters
}

\section{Zamanında Doğan Bebeklerde Umbilikal Kord Kanında Stewart Yöntemine Göre Ölçülmeyen Anyonlar ve Doku Asitleri ve Doğum Şeklinin Bu Parametrelere Etkisi}

\author{
Deniz Anuk Ince', ๑Ayse Ecevit', @Servet Ozkiraz², $\odot$ Abdullah Kurt', \\ -Hande Gülcan', @Aylin Tarcan4 \\ 'Department of Pediatrics, Division of Neonatology, Baskent University Faculty of Medicine, Ankara, Turkey \\ ${ }^{2}$ Department of Pediatrics, Division of Neonatology, Medical Park Hospital, Gaziantep, Turkey \\ ${ }^{3}$ Department of Pediatrics, Division of Neonatology, Ankara Yıldırım Beyazıt University Faculty of Medicine, Ankara, Turkey \\ ${ }^{4}$ Department of Pediatrics, Division of Neonatology, Lösante Children's and Adult Hospital, Ankara, Turkey
}

\begin{abstract}
Aim: To determine the reference values of strong ion difference (SID), effective SID (SIDe), unmeasured anions (UMA), tissue acids (TA), lactate and Chloride-Sodium ( $\mathrm{Cl}-\mathrm{Na}$ ) ratio of umbilical cord blood, and to evaluate the impact of delivery mode on these parameters.

Material and Method: This prospective study was performed on healthy term newborn infants that had normal progress throughout the first and second stages of labor during normal spontaneous delivery (NSD) and cesarean section (C/S). Immediately after birth, $1 \mathrm{ml}$ and $2 \mathrm{ml}$ of umbilical venous cord blood samples were obtained for blood gas analysis and blood chemistry respectively. The Cl-Na ratio, anion gap (AG), albumin corrected AG (AGCorr), SID, SIDe, UMA and TA were calculated in NSD and C/S groups.

Results: A total of 181 healthy newborn infants were included the study. Fifty-one infants were delivered by NSD and 130 infants by $\mathrm{C} / \mathrm{S}$. The $\mathrm{pH}$ and $\mathrm{PCO} 2$ values were similar in both groups. The mode of delivery had a significant impact on the umbilical cord AG, AGCorr, SID, lactate, UMA, and TA levels. All these values were significantly higher in NSD than C/S group.

Conclusion: Umbilical cord blood gas analysis is a common practice to evaluate fetal status at delivery. The calculation of blood gas parameters in perinatal problems according to Stewart's method may lead further understanding how perinatal conditions of the mother influence the fetus and newborn infant.

Keywords: Infants; umbilical cord; unmeasured anions; tissue acids; Stewart's method
\end{abstract}

Öz

Amaç: Umbilikal kord kanında "Strong Ion Difference' (SID), efektif SID (SIDe), ölçülmeyen anyonlar (UMA), doku asitleri (TA), laktat ve klor/sodyum ( $\mathrm{Cl}-\mathrm{Na}$ ) oranının referans değerlerini belirlemek ve bu parametrelerin doğum şekli üzerine etkisini değerlendirmektir.

Gereç ve Yöntem: Bu prospektif çalışma, sezaryen (C / S) ve doğumun birinci ve ikinci aşamalarında sorunsuz ilerleme gösteren, normal spontan doğan (NSD) sağlıklı term yenidoğan bebekler üzerinde gerçekleştirildi. Doğumdan hemen sonra, kan gazı ve biyokimya analizi için sırasıyla $1 \mathrm{ml}$ ve $2 \mathrm{ml}$ umbilikal venöz kord kanı örneği alındı. Klor/ sodyum oranı, anyon açığı (AG), albumin değerine göre düzeltilmiş AG (AGCorr), SID, SIDe, UMA ve doku asitleri her iki grupta değerlendirildi. Bulgular: Çalışmaya toplam 181 sağlıklı zamanında doğan yenidoğan bebek (NSD $n=51 ; C / S n=130$ ) dahil edildi. Parsiyel CO2 basıncı ve pH değerleri her iki grupta benzerdi. Doğum şeklinin umbilikal kord AG, AGCorr, SID, laktat, UMA ve TA seviyeleri üzerinde önemli bir etkiye sahip olduğu görüldü. Tüm parametreler NSD'de C / S grubuna göre anlamlı olarak daha yüksek bulundu.

Sonuç: Umbilikal kord kan gazı analizi doğumda fetal durumu değerlendirmede kullanılan yaygın bir uygulamadır. Perinatal problemlerde Stewart yöntemine göre kan gazı parametrelerinin hesaplanması, perinatal koşulların fetus ve yenidoğan bebeği nasıl etkilediğini daha iyi anlamaya yol açabilir.

Anahtar sözcükler: yenidoğan; umbilikal kord; ölçülmeyen anyonlar; doku asitleri; Stewart yöntemi

Corresponding (İletişim): Deniz Anuk Ince, Baskent Universitesi Hastanesi, Çocuk Sağlığı ve Hastalıkları Polikliniği Sehit Temel Kuguoglu sok. No:24 Kat:4 Bahcelievler, Çankaya, Ankara, Turkey

E-mail (E-posta): denizanuk@yahoo.com

Received (Geliş Tarihi): 03.07.2020 Accepted (Kabul Tarihi): 13.09.2020 


\section{INTRODUCTION}

Disturbances of the acid-base equilibrium happen in numerous vital illnesses. These are one of the most commonly disorders in the neonatal intensive care units (NICUs). ${ }^{[1-3]}$ While the most of acid-base disturbances are easily explained, some of them are complicated. ${ }^{[1-3]}$ Metabolic acidosis may be caused by elevated tissue acids (TA), hyperchloremia or a combination of the two. Tissue acids comprise lactate and/or unmeasured anions (UMA). Evaluation and analysis of acid-base disorders, a combination of three factors has been used by the classical Siggaard-Anderson approach. Henderson-Hasselbalch $(\mathrm{H}-\mathrm{H})$ equation, the base excess (BE), and anion gap (AG) are used in this method. This approach seems inadequate because of the fact that it is completely dependent on bicarbonates and $\mathrm{PaCO}_{2}{ }^{[1,2]}$ The respiratory variable $\left(\mathrm{PaCO}_{2}\right)$ and the metabolic variable $\left(\mathrm{HCO}_{3}{ }^{-}\right)$affect the blood $\mathrm{pH}$. On the other hand, the presence of weak acids like albumin is not counted by the plasma $\mathrm{pH}$ value in Henderson-Hasselbalch equation. ${ }^{[1,2,4]}$ So a patient with hypoalbuminemia and lactic acidosis will be associated with normal anion gap. ${ }^{[4-9]}$ The AG is calculated as the difference between the sum of cations and anions found in the plasma. It is formulated like $A G=\left[\mathrm{Na}^{+}\right]+\left[\mathrm{K}^{+}\right]-\left[\mathrm{Cl}^{-}\right]-\left[\mathrm{HCO}_{3}^{-}\right]$. ${ }^{[1,2]}$ Anion gap is grossly underestimated in the presence of hypoalbuminemia, which is a frequent occurrence in critically ill patients. Therefore, correction of AG (AGcorr) for serum albumin improves the accuracy of this parameter. In contrast to $\mathrm{H}-\mathrm{H}$ method, Stewart's physiochemical method accurately quantifies direct contribution of UMA and TA to a metabolic acidosis, hence defining the cause. But, this method needs a complex mathematical calculation system.

Stewart's physiochemical approach elucidated a new model of acid-base balance in 1981. ${ }^{[10]}$ This theory states that three independent variables determine $\mathrm{pH}$ in changing the degree of water dissociation into hydrogen ions. The three independent variables are the strong ion difference (SID), the total weak acids $\left(\mathrm{A}_{\mathrm{Tot}}\right)$, and the partial pressure of carbon dioxide $\left(\mathrm{pCO}_{2}\right)_{.}{ }^{[1,10]}$ The serum bicarbonate concentration does not alter blood $\mathrm{pH}$ in Stewart's approach. Albumin is the major additional variable of acid base analysis in Stewart's method. Strong ion difference in Stewart's approach is difference between the sums of concentrations of the strong cations and strong ions; SID is formulated as

$[\mathrm{SID}]=\left[\mathrm{Na}^{+}\right]+\left[\mathrm{K}^{+}\right]+\left[\mathrm{Ca}_{2}^{+}\right]+\left[\mathrm{Mg}_{2}^{+}\right]-\left[\mathrm{CL}^{-}\right]=40-44 \mathrm{mEq} / \mathrm{L}$. The $A_{\text {Tot }}$ is the total plasma concentration of the weak acids which are phosphate, serum protein and albumin. In a variety of pathological conditions, additional strong anions, which include lactate, formate, ketoacids, and sulphate, may become elevated. Therefore these unmeasured anions (UMA) will change the SID such that the effective SID (SIDe) becomes $\mathrm{SIDe}=\left[\mathrm{HCO}_{3}{ }^{-}\right]+0.28 \times[$ albumin $(\mathrm{g} / \mathrm{l})]+1.8 \times[$ phosphate $(\mathrm{mmol} / \mathrm{l})]$. $[10,12,13]$ The difference between SID and SIDe is defined as strong ion gap (SIG) which reflects the UMA and lactate. ${ }^{[4,11,12]}$

Fetus, in- utero just before delivery, is affected by the normal physiologic changes of acid base status. Umbilical cord blood gas analysis is a common practice to evaluate fetal status at delivery. ${ }^{[14]}$ Postnatal $\mathrm{pH}$ and base deficit has been used to assess the degree of acidemia and prediction of neonatal morbidity. ${ }^{[15]}$ In literature only a pilot study was encountered that evaluates the SID values in umbilical cord blood.[16] Therefore, we aimed:

- to determine the reference values of SID, SIDe, UMA, TA, lactate and $\mathrm{Cl}-\mathrm{Na}$ ratio of umbilical cord blood in a larger study group,

- to evaluate the impact of delivery mode on SID, SIDe, UMA, TA, and lactate levels of umbilical cord blood.

\section{PATIENTS AND METHODS}

This prospective study was performed on healthy term newborn infants who were born at Baskent University Faculty of Medicine in 1 year period. The study was approved by the Institutional Review Board (IRB) and Ethic Committee of Baskent University Faculty of Medicine (KA11/64). The newborn infants that had normal progress throughout the first and second stages of labor during vaginal delivery and cesarean delivery were included the study. Exclusion criteria were maternal hypertensive disorders, maternal diabetes, fetal anomaly, fetal growth restriction, placental abruption, clinical chorioamnionitis, nonreassuring fetal heart rate, fetal/cord anomaly, umbilical cord prolapse, postterm pregnancy, vaginal birth after cesarean, nuchal or body cord, two vessel cords, shoulder dystocia and instrumental delivery. Subjects with histological funisitis or chorioamnionitis following premature rupture of membranes were excluded. The exclusion criteria for newborn infants were NICU admission for any reason. The newborn infants who had emergency cesarean section for fetal indications, multiple congenital anomalies, inborn metabolic diseases, congenital heart diseases, renal failure were also excluded. Immediately after birth, $1 \mathrm{ml}$ and $2 \mathrm{ml}$ of umbilical venous cord blood samples were obtained from healthy infants for blood gas analysis and blood chemistry respectively. Strong ions like $\mathrm{Na}^{+}, \mathrm{K}^{+} \mathrm{Ca}^{2+}, \mathrm{Mg}^{2+}, \mathrm{Cl}^{-}$, lactate and weak acid (albumin) were studied. The $\mathrm{Cl}-\mathrm{Na}$ ratio, DiffNaCl, $\mathrm{AG}$, albumin corrected AG, $A G_{\text {Corr' }}$ SID, SIDe, UMA and TA were calculated for each healthy infant. Samples were analyzed for complete blood chemistry, lactate, and blood gas parameters using the both by Handerson-Hasselbach and Stewart's methods.

The concentrations of $\mathrm{Na}^{+}, \mathrm{K}^{+}, \mathrm{Mg}^{+2}$ and $\mathrm{Cl}^{-}$were analyzed by automated ion-specific electrodes, and albumin was analyzed by bromocresol green dye binding. Blood gases, $\mathrm{iCa}^{2+}, \mathrm{pH}$ and lactate were analyzed with an automated $\mathrm{pH}$ blood gas analyzer. Albumin was converted $\mathrm{mg} / \mathrm{dL}$ to $\mathrm{g} / \mathrm{L}$ [Albumin $(\mathrm{g} / \mathrm{l})=10 x a l b u m i n(\mathrm{mg} / \mathrm{dl})$ ]. The AG was difference between measured cations $(\mathrm{Na}+\mathrm{K})$ and measured anions (actual bicarbonate $+\mathrm{Cl})$. $\left(\mathrm{AG}=\left[\mathrm{Na}^{+}\right]+\left[\mathrm{K}^{+}\right]-\left[\mathrm{Cl}^{-}\right]-\left[\mathrm{HCO}_{3}^{-}\right]\right)$. At the same time corrected $A G\left(A G_{\text {corr }}\right)$ were calculated $\left(A G_{\text {Corr }}=\left(A G+(0.25 \times[44-\right.\right.$ measured albumin $g / L)] .^{[12]}$ The SID is formulated as $\left.\mathrm{SID}=\left[\mathrm{Na}^{+}\right]+\left[\mathrm{K}^{+}\right]+\left[\mathrm{Ca}^{2+}\right]+\left[\mathrm{Mg}^{2+}\right]-\left[\mathrm{Cl}^{-}\right]\right)$. The SIDe and UMA are formulated as; $\mathrm{SIDe}=\left[\mathrm{HCO}_{3}{ }^{-}+0.28 \times[\right.$ albumin $(\mathrm{g} / \mathrm{l})]+$ 
$1.8 \times[$ phosphate $(\mathrm{mmol} / \mathrm{L}]$ and UMA=SID-SIDe respectively. [10-12,16] Tissue acids are calculated as; TA=lactate + UMA. The anionic effect of albumin and phosphate is measured by using the formula: $(\mathrm{mEq} / \mathrm{L})=\left[\right.$ albumin] $\mathrm{g} / \mathrm{L} \times(0.123 \times \mathrm{pH}-0.631){ }^{[12]}$ In our study serum phosphate levels could not measured. In order that the level of phosphate was assumed as $2 \mathrm{mEq} / \mathrm{L}$ which were normal value for healthy newborn infants. ${ }^{[13]}$ The $\mathrm{Cl}-\mathrm{Na}$ ratio and difference between $\mathrm{Na}$ and $\mathrm{Cl}$ (DiffNaCl) values of all newborn infants were also calculated.

For statistical evaluation SPSS for Windows SPSS software (Statistical Package for Social Sciences, version 17.0, SPSS Inc., Chicago, III, USA) was used. Normal distribution and homogeneity of the variances was evaluated using Kolmorov Simirnov test. All data except anion gap measured according to albumin and $\mathrm{Cl}-\mathrm{Na}$ ratio were compatible with normal distribution. Mean \pm standard deviation, $95 \% \mathrm{Cl}$ values, percentiles and extreme values were calculated. T-test was used for the comparison of delivery route. Pre-conditions that do not meet the test for parametric variables, MannWhitney-U test was used when comparing the two groups.

\begin{tabular}{|c|c|c|}
\hline General evidence & Total & Range \\
\hline n (female/male) & $181(85 / 96)$ & \\
\hline GA (weeks) & $38.5 \pm 1.0$ & $(37-41)$ \\
\hline Weight (g) & $3317.2 \pm 456.0$ & $(2190-4500)$ \\
\hline Apgar 1. min score & $8.1 \pm 0.7$ & $(6-10)$ \\
\hline Apgar 5. min score & $9.5 \pm 0.5$ & $(8-10)$ \\
\hline Electrolytes & & $95 \% \mathrm{Cl}$ \\
\hline $\mathrm{Na}(\mathrm{mEq} / \mathrm{L})$ & $136.56 \pm 0.22$ & $136.05-137.03$ \\
\hline $\mathrm{K}(\mathrm{mEq} / \mathrm{L})$ & $4.61 \pm 0.06$ & 4.58-4.83 \\
\hline $\mathrm{Cl}(\mathrm{mEq} / \mathrm{L})$ & $106.48 \pm 0.20$ & 106.21-107.06 \\
\hline $\mathrm{Ca}(\mathrm{mmol} / \mathrm{L})$ & $2.41 \pm 0.11$ & $2.39-2.44$ \\
\hline $\mathrm{Mg}(\mathrm{mmol} / \mathrm{L})$ & $0.71 \pm 0.00$ & $0.69-0.72$ \\
\hline Phosphate (mEq/L) & 2.0 (assumed) & - \\
\hline Albumin (g/L) & $3.35 \pm 0.23$ & $3.28-3.38$ \\
\hline \multicolumn{3}{|c|}{ Blood gas parameters (Traditional acid base data) } \\
\hline $\mathrm{pH}$ & $7.31 \pm 0.00$ & $7.30-7.32$ \\
\hline $\mathrm{pCO} 2(\mathrm{mmHg})$ & $47.09 \pm 0.68$ & $45.44-48.41$ \\
\hline Actual bicarbonate(mmol/L) & $23.66 \pm 0.29$ & $22.59-23.76$ \\
\hline Standard bicarbonate $(\mathrm{mmol} / \mathrm{L})$ & $20.80 \pm 0.28$ & $20.25-21.36$ \\
\hline Base deficit Ecf. (mmol/L) & $-1.80 \pm 0.34$ & $-2.99--1.60$ \\
\hline Base deficit B. (mmol/L) & $-1.84 \pm 0.32$ & $-2.98--1.66$ \\
\hline Lactate (mmol/L) & $1.96 \pm 0.09$ & $1.77-2.20$ \\
\hline Anion gap & $11.03 \pm 0.40$ & $10.56-12.30$ \\
\hline AGCorr & $13.64 \pm 0.40$ & $13.22-14.95$ \\
\hline \multicolumn{3}{|l|}{ According to Stewart acid-base theory } \\
\hline $\mathrm{SID}(\mathrm{mEq} / \mathrm{L})$ & $37.83 \pm 0.28$ & $37.13-38.36$ \\
\hline SIDe (mEq/L) & $36.66 \pm 0.30$ & $35.52-36.72$ \\
\hline DiffNacl & $30.08 \pm 0.30$ & $29.24-30.56$ \\
\hline UMA (mEq/L) & $1.17 \pm 0.40$ & $0.75-2.48$ \\
\hline $\mathrm{TA}(\mathrm{mEq} / \mathrm{L})$ & $3.14 \pm 0.44$ & $2.64-4.56$ \\
\hline $\mathrm{Cl}: \mathrm{Na}$ & $0.78 \pm 0.00$ & $0.77-0.78$ \\
\hline
\end{tabular}

Confidence level for all analyzes (Type 1 error) was kept at $a=0.05$. Chi-square test was performed in order to determine the relationship of categorical data.

\section{RESULTS}

A total of 181 healthy newborn infants who were born at Baskent University Faculty of Medicine were included the study. Fifty-one were in NSD and 130 were in C/S group. The $\mathrm{pH}$ and $\mathrm{PCO}_{2}$ values were similar in both groups. Demographical and laboratory data of all participants were given in Table $\mathbf{1}$. Data according to the delivery mode were given in Table $\mathbf{2}$. The blood chemistry analyses and blood gas analysis were studied from umbilical venous cord for each infant. Strong ions as $\mathrm{Na}^{+}, \mathrm{K}^{+}, \mathrm{Ca}^{2+}, \mathrm{Mg}^{2+}, \mathrm{Cl}^{-}$, lactate and weak acid (albumin) were studied. The percentiles of $\mathrm{Cl}-\mathrm{Na}$ ratio, DiffNaCl, AG, $\mathrm{AG}_{\text {Corr' }}$ SID, SIDe, UMA and TA were also calculated according to the delivery mode, and were given in Table 3.

Table 2. Demographical data and laboratory test results for normal spontaneous delivery or cesarean section

\begin{tabular}{|c|c|c|c|}
\hline & $\begin{array}{c}\text { Normal } \\
\text { spontaneous } \\
\text { delivery } \\
(n=51)\end{array}$ & $\begin{array}{l}\text { Cesarean } \\
\text { section } \\
(n=130)\end{array}$ & $\begin{array}{c}p \\
\text { value }\end{array}$ \\
\hline Gender (female/male) & $51(25 / 26)$ & $130(60 / 70)$ & $0.728^{* *}$ \\
\hline GA (weeks) & $39.0 \pm 1.1$ & $38.3 \pm 1.0$ & $0.000^{*}$ \\
\hline Weight (g) & $3263.3 \pm 385.7$ & $3338.3 \pm 480.5$ & $0.224^{*}$ \\
\hline Apgar 1. min score & $7.9 \pm 0.7$ & $8.1 \pm 0.7$ & $0.056^{*}$ \\
\hline Apgar 5. min score & $9.6 \pm 0.5$ & $9.5 \pm 0.5$ & $0.627^{*}$ \\
\hline \multicolumn{4}{|l|}{ Electrolytes...Y } \\
\hline $\mathrm{Na}(\mathrm{mEq} / \mathrm{L})$ & $136.52 \pm 0.52$ & $136.58 \pm 0.23$ & $0.697^{*}$ \\
\hline $\mathrm{K}(\mathrm{mEq} / \mathrm{L})$ & $4.57 \pm 0.10$ & $4.63 \pm 0.07$ & $0.933^{*}$ \\
\hline $\mathrm{Cl}(\mathrm{mEq} / \mathrm{L})$ & $105.47 \pm 0.44$ & $106.87 \pm 0.21$ & $0.003^{*}$ \\
\hline $\mathrm{Ca}(\mathrm{mmol} / \mathrm{L})$ & $2.45 \pm 0.02$ & $2.40 \pm 0.01$ & $0.019^{*}$ \\
\hline $\mathrm{Mg}(\mathrm{mmol} / \mathrm{L})$ & $0.77 \pm 0.02$ & $0.68 \pm 0.00$ & $0.001^{*}$ \\
\hline Phosphate (mEq/L) & 2.0 (assumed) & 2.0 (assumed) & 1.0 \\
\hline Albumin $(\mathrm{g} / \mathrm{L})$ & $34.73 \pm 0.47$ & $33.08 \pm 0.26$ & $0.013^{*}$ \\
\hline \multicolumn{4}{|c|}{ Blood gas parameters (Traditional acid-base data) $\gamma$} \\
\hline $\mathrm{pH}$ & $7.30 \pm 0.01$ & $7.31 \pm 0.00$ & $0.592^{*}$ \\
\hline $\mathrm{pCO} 2(\mathrm{mmHg})$ & $45.2 \pm 1.5$ & $47.81 \pm 0.72$ & $0.061^{*}$ \\
\hline Actual bicarbonate(mmol/l) & $21.80 \pm 0.49$ & $24.39 \pm 0.33$ & $0.000^{*}$ \\
\hline Standard bicarbonate $(\mathrm{mmol} / \mathrm{l})$ & $19.29 \pm 0.45$ & $21.44 \pm 0.33$ & $0.000^{*}$ \\
\hline Base deficit Ecf. (mmol/l) & $-3.54 \pm 0.65$ & $-1.10 \pm 0.38$ & $0.001^{*}$ \\
\hline Base deficit B. (mmol/l) & $-3.43 \pm 0.62$ & $-1.20 \pm 0.36$ & $0.002^{*}$ \\
\hline Lactate $(\mathrm{mmol} / \mathrm{l})$ & $2.87 \pm 0.27$ & $1.61 \pm 0.05$ & $0.000^{*}$ \\
\hline Anion gap & $13.82 \pm 0.86$ & $9.94 \pm 0.41$ & $0.000^{*}$ \\
\hline AGCorr & $16.14 \pm 0.84$ & $12.66 \pm 0.43$ & $0.000^{*}$ \\
\hline \multicolumn{4}{|c|}{ According to Stewart acid-base theory $\gamma$} \\
\hline $\mathrm{SID}(\mathrm{mEq} / \mathrm{L})$ & $38.86 \pm 0.69$ & $37.42 \pm 0.28$ & $0.023^{*}$ \\
\hline SIDe (mEq/L) & $35.13 \pm 0.51$ & $37.26 \pm 0.35$ & $0.000^{*}$ \\
\hline DiffNacl & $31.05 \pm 0.72$ & $29.70 \pm 0.31$ & $0.048^{*}$ \\
\hline UMA (mEq/L) & $3.72 \pm 0.83$ & $0.16 \pm 0.43$ & $0.000^{*}$ \\
\hline $\mathrm{TA}(\mathrm{mEq} / \mathrm{L})$ & $6.60 \pm 0.96$ & $1.78 \pm 0.44$ & $0.000^{*}$ \\
\hline $\mathrm{Cl}: \mathrm{Na}$ & $0.77 \pm 0.00$ & $0.78 \pm 0.00$ & $0.026^{*}$ \\
\hline
\end{tabular}

AG:Anion gap. AGCorr: Albumin corrected AG. SID: strong ion difference. SIDe: effective strong ion difference. UMA: Unmeasured anions. DiffNaCl: Difference between Na and Cl. TA: Tissue acids. GA: Gestational age. Min: Minute. *: Mann-Whitney U test. **:Chi-Square test. ; mean \pm St.Deviation. $\Gamma$ : Mean \pm St.Erorr 
Table 3. Percentiles of pH, pCO2, Actual bicarbonate, Standard bicarbonate, Standard bicarbonate Ecf., Base deficit B, Anion gap, AGCorr, SID, DiffNaCl, UMA, $\mathrm{TA}, \mathrm{Cl}-\mathrm{Na}$ ratio according to the delivery modes

\begin{tabular}{|c|c|c|c|c|c|c|c|c|c|}
\hline \multirow[b]{2}{*}{ Percentiles } & \multicolumn{3}{|c|}{ Normal spontaneous delivery $(n=51)$} & \multicolumn{3}{|c|}{ Cesarean section $(n=130)$} & \multicolumn{3}{|c|}{ Total $(n=181)$} \\
\hline & 25 & 50 & 75 & 25 & 50 & 75 & 25 & 50 & 75 \\
\hline $\mathrm{pH}$ & 7.27 & 7.30 & 7.36 & 7.28 & 7.31 & 7.35 & 7.28 & 7.31 & 7.35 \\
\hline Actual bicarbonate $(\mathrm{mmol} / \mathrm{l})$ & 19.05 & 21.70 & 23.75 & 22.20 & 24.30 & 26.20 & 21.20 & 23.70 & 26.0 \\
\hline Standard bicarbonate $(\mathrm{mmol} / \mathrm{l})$ & 17.55 & 19.55 & 21.15 & 20.30 & 21.60 & 22.90 & 19.40 & 21.00 & 22.50 \\
\hline Lactate & 1.50 & 2.10 & 3.40 & 1.20 & 1.50 & 1.82 & 1.30 & 1.60 & 2.10 \\
\hline Anion gap & 9.40 & 13.15 & 17.70 & 6.69 & 9.60 & 12.14 & 7.23 & 9.90 & 13.67 \\
\hline AGCorr & 11.95 & 15.32 & 20.46 & 9.04 & 12.01 & 15.48 & 9.92 & 12.70 & 16.21 \\
\hline SID & 35.58 & 38.38 & 42.33 & 35.06 & 37.21 & 39.04 & 35.31 & 37.49 & 39.98 \\
\hline TA & 2.41 & 6.48 & 10.92 & -1.06 & 1.63 & 4.53 & -.26 & 2.38 & 6.59 \\
\hline $\mathrm{Cl}-\mathrm{Na}$ ratio & .74 & .77 & .79 & .76 & .78 & .80 & .76 & .78 & .79 \\
\hline
\end{tabular}

\section{DISCUSSION}

In this study, cord blood UMA and TA levels of healthy newborn infants born after uncomplicated pregnancies and deliveries were calculated according to Stewart's approach. Impact of delivery modes on these levels was also compared. Result of all healthy newborn infants for SIG (UMA) was found $1.17 \pm 0.40$ and TA was found $3.14 \pm 0.44 \mathrm{mEq} / \mathrm{L}$. The SID and SIDe were $37.83 \pm 0.28$ and $36.66 \pm 0.30 \mathrm{mEq} / \mathrm{L}$ respectively. The normal levels of SID, SIDe and SIG in adult population have been previously reported, these were found $41.4 \pm 3.7,40 \pm 3.8$ and $1.4 \pm 1.8 \mathrm{mEq} / \mathrm{L}$ respectively. ${ }^{[15]}$ The slight differences between cord and adult blood can be explained by relatively higher values of $\mathrm{Cl}$ in cord blood of our study group.

We also found that mode of delivery has a significant impact on the umbilical cord SID, SIDe, lactate, UMA, and TA levels. A recently published study which was done by Khoshnow et al. ${ }^{[17]}$ found that the lowest lactate levels were noted among newborns delivered by elective caesarean sections (C/S) group than normal spontaneous delivery (NSD) group. In Khoshnow's study lactate levels with elective C/S and NSD were $3.24 \mathrm{mmol} / \mathrm{L}$ and $4.31 \mathrm{mmol} / \mathrm{L}$ respectively. ${ }^{[17]} \mathrm{In}$ our study, cord blood lactate levels were $2.87 \pm 0.27 \mathrm{mmol} / \mathrm{L}$ with NSD and $1.61 \pm 0.05 \mathrm{mmol} / \mathrm{L}$ with $\mathrm{C} / \mathrm{S}$ delivery. Another study which was reported by Cohen $Y$ et al. ${ }^{[16]}$ found that lactate levels were lower in the cesarean section group than vaginal birth group. This result was similar to our study but lactate levels were lower than that study. Lactate levels with $\mathrm{C} / \mathrm{S}$ and NSD were $2.87 \pm 1.52$ and $4.19 \pm 1.47$ respectively in Cohen et al. study. The cord blood values of two studies revealed that lactate levels were significantly different according to the mode of delivery. While Cohen et al. ${ }^{[16]}$ showed that there was no difference between delivery modes for SID, SIDe was significantly ( $p=0.000$ ) different after the $C / S$ compared the NSD in our study. In a meta-analysis, Reynolds and Seed ${ }^{[18]}$ compared to general and epidural anesthesia and reported that umbilical cord artery $\mathrm{pH}$ was significantly lower and $\mathrm{BE}$ was significantly higher in spinal anesthesia group. Several pediatric studies have showed that the prognostic value of lactate is better. ${ }^{[17]}$ But, in the study of Durward et al. ${ }^{[19]}$ UMA increased alone in about half of cases of metabolic acidosis, whereas isolated lactate elevation was very rare. Elevated lactate was frequently associated with increased UMA. ${ }^{[19]}$ Although the exact nature and chemical composition of UMA remain unknown, UMA in metabolic acidosis gives accurate representation of TA production. Furthermore, it is clinically important. A previous study revealed that, UMA was more remarkable than other conventional variables $(\mathrm{pH}, \mathrm{BD}$, and lactate) in identifying non-survivors among critically ill children ${ }^{[5]}$ In maternal and fetal high risk conditions, UMA may represent the acute problems better than lactate. Therefore it can be used as a parameter in the diagnosis of perinatal hypoxia.

Metabolic acidosis is a common finding in critically ill neonates, before treating a laboratory value, it is important to consider the underlying cause. ${ }^{[20]}$ Also our study provides important evidence on umbilical cord blood UMA and TA reference values. The UMA variations according to early postnatal problems can be detected based on these normal cord blood references. Another important result is calculation of $\mathrm{Cl}-\mathrm{Na}$ ratio and DiffNaCl levels that can be used as a simple bedside tool an easy alternative to corrected AG. Nagaoka et al. ${ }^{[21]}$ reported that both the $\mathrm{Cl}-\mathrm{Na}$ ratio and $\mathrm{DiffNaCl}$ are good tools to disclose SID in critically ill adults. Its usefulness in pediatric and neonatal studies was shown in several other studies. ${ }^{[1,5,19,22]}$ 
Our previous study revealed that $\mathrm{DiffNaCl}$ and the $\mathrm{Cl}: \mathrm{Na}$ ratio were simple, quick and may be alternative methods to the Stewart's approach in identifying raised UMA and TA in both critically ill term and preterm infants hospitalized in NICUs. ${ }^{[2]}$ Durward et al. ${ }^{[2]}$ investigate 540 blood gas measurements in a pediatric age group hospitalized at a pediatric intensive care unit. They conclude that a $\mathrm{Cl}-\mathrm{Na}$ ratio $<0.75$ is a good predictor of increased TA (PPV $=88 \%)$. Conversely, a high ratio $(>0.79)$ excluded increased TA (PPV=81\%, LR=4.5). Base deficit (BD) and lactate affected poorly. ${ }^{[2]}$ In our study umbilical venous $25 \mathrm{p}-50 \mathrm{p}$ $75 \mathrm{p}$ values of $\mathrm{Cl}-\mathrm{Na}$ ratio were $0.74,0.77,0.79$ after NSD; 0.76, $0.78,0.80$ after $C / S$; and $0.76,0.78,0.79$ in total respectively. These results were similar with Durward's results. ${ }^{[1]}$

In addition at early postnatal period, the treatment is controversial in a few conditions such as asymptomatic hypotension and anemia. Unmeasured anions can be helpful to show the effects of these conditions on tissue level. Unmeasured anions with or without lactate can be used to individualize the treatment in such controversial conditions. ${ }^{[23-25]}$ Another important result of this study is the impact of mode of delivery on the TA levels. Fetus in- utero just before delivery effected by the normal physiologic changes of acid base status. Umbilical cord blood gas analysis is a common practice to evaluate fetal status at delivery. ${ }^{[2,27]}$ Postnatal $\mathrm{pH}$ and base deficit has been used to assess the degree of acidemia and prediction of neonatal morbidity. ${ }^{[15]}$

The limitation of our study is the number of patient group that larger patient group are needed to understand the effect of the perinatal conditions on fetus and infant. Also maternal risk factors can also be examined detailed.

\section{CONCLUSION}

The calculation of blood gas parameters in perinatal problems according to Stewart's method may lead further understanding how perinatal conditions of the mother influence the fetus and newborn infant.

\section{ETHICAL DECLARATIONS}

Ethics Committee Approval: The study was carried out with the permission of Ethic Committee of Baskent University Faculty of Medicine (KA11/64).

Informed Consent: All patients signed the free and informed consent form.

Referee Evaluation Process: Externally peer-reviewed.

Conflict of Interest Statement: The authors have no conflicts of interest to declare.

Financial Disclosure: The authors declared that this study has received no financial support.

Author Contributions: All of the authors declare that they have all participated in the design, execution, and analysis of the paper, and that they have approved the final version.

\section{REFERENCES}

1. Durward A, Murdoch I. Understanding acid-base balance. Current Paediatrics 2003;13:513-9.

2. Durward A, Skellett S, Mayer A, Taylor D, Tibby SM, Murdoch IA. The value of the chloride: sodium ratio in differentiating the aetiology of metabolic acidosis. Intens Care Med 2001;27:828-35.

3. Gomez H, Kellum JA. Understanding Acid Base Disorders. Crit Care Clin 2015;31(4):849-60.

4. Kellum JA. Metabolic acidosis in the critically ill: lessons from physical chemistry. Kidney 1998;66:81-6.

5. Balasubramanyan N, Havens PL, Hoffman GM. Unmeasured anions identified by the Fencl Stewart method predict mortality better than base excess. anion gap. and lactate in patients in the pediatric intensive care unit. Crit Care Med 1999;27:1577-81.

6. Fidkowski C, Helstrom J. Diagnosing metabolic acidosis in the critically ill: bridging the anion gap, Stewart and base ecess methods. Can J Anesth 2009;56:247-56.

7. Moviat M, Terpstra AM, Ruitenbeek W, Kluijtmans LA, Pickkers P, van der Hoeven JG. Contribution of various metabolites to the "unmeasured" anions in critically ill patients with metabolic acidosis. Crit Care Med 2008;36:752-8

8. Moviat M, van Haren F, van der Hoeven H. Conventional or physiochemical approach in intensive care unit patients with metabolic acidosis. Crit Care 2003;7:41-5.

9. Murray DM, Olhsson V, Fraser I. Defining acidosis in postoperative cardiac patients using Stewart's method of strong ion difference. Pediatr Crit Care Med 2004;5:240-5.

10. Stewart PA. Modern quantitative acid-base chemistry. Can J Physiol Pharmacol 1983;61:1444-61.

11. Fencl V, Leith DE. Stewart's quantitative acid-base chemistry: applications in biology and medicine. Respir Physiol 1993;91:1-16.

12. Figge J, Mydosh T, Fencle V. Serum proteins and acid-base equilibria: a follow up. J Lab Clin Med 1992;120:713-9.

13. Morris CG, Low J. Metabolic acidosis in the critically ill: Part 1. Classification and pathophysiology. Anaesthesia 2008;63:294-301.

14. ACOG Committee on Obstetric Practice. ACOG Committee Opinion No. 348. November 2006: umbilical cord blood gas and acid-base analysis. Obstet Gynecol 2006;108:1319-22.

15. Goldaber KG, Gilstrap LC 3rd, Leveno KJ, Dax JS, McIntire DD. Pathologic fetal acidemia. Obstet Gynecol 1991;78:1103-7.

16. Cohen Y,Nimord A, Ascher-Landsberg J, Kupferminc MJ, Lessing JB, Many A. Reference values for strong ion difference-A novel tool for fetal metabolic assessment. Eur J Obstet Gynecol Reprod Biol 2009;145:145-8.

17. Khoshnow Q,Mongelli M. Cord blood lactate and $\mathrm{pH}$ values at term and perinatal outcome: A Retrospective Cohort Study. Webmed Central Obstetrics and Gynaecology 2010:1(9):WMC00694.

18. Reynolds F, Seed PT. Anaesthesia for caesarean section and neonatal acid-base status: a meta-analysis. Anaesthesia 2005;60:636-53.

19. Durward A, Tibby SM, Skellet S, Austin C, Anderson D, Murdoch IA. The strong ion gap predicts mortality in children following cardiopulmonary bypass surgery. Pediatr Crit Care Med 2005;6:281-5.

20. Aschner JL, Poland RL. Sodium bicarbonate: basically useless therapy. Pediatrics 2008;122:831-5.

21. Nagaoka D, Nassar AP, Maciel AT, et al. The use of sodium-chloride difference and chloride-sodium ratio as strong ion difference surrogates in the evaluation of metabolic acidosis in critically ill patients. J Crit Care 2010;55:525-31. 
22. Kurt A, Ecevit A, Ozkiraz S, Ince DA, Akcan AB, Tarcan A. The use of chloride-sodium ratio in the evaluation of metabolic acidosis in critically ill neonates. Eur J Pediatr 2012; 171:963-9.

23. Barrington KJ. Low blood pressure in extremely preterm infants: does treatment affect outcome? Arch Dis Child Fetal Neonatal Ed 2011;96:3167.

24. Dempsey EM, Al Hazzani F, Barrington KJ. Permissive hypotension in the extremely low birthweight infant with signs of good perfusion. Arch Dis Child Fetal Neonatal Ed 2009;94:241-4.

25. Whyte RK, Kirpalani H, Asztalos EV, et al. Neurodevelopmental outcome of extremely low birth weight infants randomly assigned to restrictive or liberal hemoglobin thresholds for blood transfusion. Pediatrics 2009;123:207-13.

26. Johnson JW, Riley W. Cord blood gas studies: a survey. Clin Obstet Gynecol 1993;36:99-101.

27. Thorp JA, Rushing RS. Umbilical cord blood gas analysis. Obstet Gynecol Clin North Am 1999;26:695-709. 